Abstracta Iranica Abstracta Iranica

Revue bibliographique pour le domaine irano-aryen

Volume 28 | 2007

Comptes rendus des publications de 2005

\title{
The World Turned Inside Out. Henry Corbin and Islamic Mysticism. Woodstock, Connecticut, Spring Journal Books, 2003, 210 p.
}

Pierre Lory

\section{(2) OpenEdition}

Journals

Édition électronique

URL : http://journals.openedition.org/abstractairanica/12432

DOI : 10.4000/abstractairanica. 12432

ISSN : 1961-960X

Éditeur :

CNRS (UMR 7528 Mondes iraniens et indiens), Éditions de l'IFRI

\section{Édition imprimée}

Date de publication : 15 mai 2007

ISSN : 0240-8910

Référence électronique

Pierre Lory, «The World Turned Inside Out. Henry Corbin and Islamic Mysticism. Woodstock, Connecticut, Spring Journal Books, 2003, 210 p. », Abstracta Iranica [En ligne], Volume 28 | 2007 document 263, mis en ligne le 18 septembre 2007, consulté le 25 septembre 2020. URL : http:// journals.openedition.org/abstractairanica/12432; DOI : https://doi.org/10.4000/abstractairanica. 12432

Ce document a été généré automatiquement le 25 septembre 2020.

Tous droits réservés 


\title{
The World Turned Inside Out. Henry Corbin and Islamic Mysticism. Woodstock, Connecticut, Spring Journal Books, 2003, 210 p.
}

\section{Pierre Lory}

\begin{abstract}
Nous avons affaire ici à une présentation des enjeux philosophiques de l'œuvre de Corbin, de la part d'un essayiste américain qui ne se définit nullement comme 'orientaliste'. Le parcours de Corbin est tracé depuis la philosophie heideggerienne, passant par l'exploration de l'Iran mazdéen, jusqu'aux thèmes principaux des ésotérismes chiites et soufis : le rapport de l'apparent et du caché, l'enjeu de l'exégèse symbolique ( $t a^{\prime}$ 'vil), le « combat pour l'ange "... L'A. dessine une synthèse de l'attitude de la spiritualité des religions du Livre selon la spiritualité islamique, où l'exégèse devient le point d'appui vers la transformation du sujet, et l'accomplissement de celui-ci dans une tension vers la transcendance (la « rencontre avec l'ange»). L'ouvrage souligne l'intérêt de l'œuvre d'islamisant de Corbin pour un public occidental non musulman d'un point de vue non confessionnel, ouvert à un nouveau type d'humanisme.
\end{abstract}

\section{INDEX}

Thèmes : 7. Islam 
AUTEURS

PIERRE LORY

EPHE - Paris 